\title{
In vitro and in vivo antioxidant activity of the pulp of Jatobá-do-cerrado
}

\author{
Daniela Granja ARAKAKI ${ }^{1 *}$, Camila Jordão CANDIDO², Anderson Fernandes da SILVA ${ }^{3}$, \\ Rita de Cássia Avellaneda GUIMARÃES ${ }^{3}$, Priscila Aiko HIANE²
}

\begin{abstract}
Oxygen metabolism in cells causes the production of free radicals, which produce damage, including changes in cell structure and function. Antioxidants are substances that, at low concentrations, slow down or prevent oxidation. Fruits and vegetables contribute to the dietary supply of these compounds. The flora of the Cerrado in Brazil has shown to have high levels of bioactive compounds. This study aimed to characterize the antioxidant activity of the pulp of jatobá-do-cerrado in vitro and in vivo. In vitro antioxidant activity of the aqueous, ethanol and aqueous acetone extracts was evaluated by the DPPH method. We determined total phenols by the Folin-Ciocalteu assay and tannins by the Folin-Denis method. In vivo antioxidant potential of the aqueous acetone extract was evaluated by the TBARS technique. The aqueous acetone extract had the highest antioxidant capacity, followed by the aqueous and ethanol extracts. The same pattern occurred in the extraction of phenols and in the extraction of tannins. In vivo administration of the aqueous acetone extract inhibited lipid peroxidation compared to the control group. The inhibition of peroxidation has increased by elevating the dosage concentration of the extracts, demonstrating a significant antioxidant potential in vivo as well as in vitro.
\end{abstract}

Keywords: bioactive compounds; rats; fruits of cerrado.

Practical Application: The bioactives found in jatobá demonstrated to be antioxidant in vitro and in vivo.

\section{Introduction}

The oxidative process is used for the production of energy required for essential cell activities; however, oxygen metabolism in the cells also causes the production of free radicals. Oxidizing agents are compounds produced by metabolism, and if not controlled, can cause damage (Alves et al., 2010).

Antioxidants can be defined as substances that at low concentrations retard or prevent the oxidation of a substrate (Sucupira et al., 2012). They are responsible for the inhibition and reduction of lesions caused by free radicals in cells (Abrahão et al., 2012). Among the foods that contain natural antioxidants, fruits and vegetables are the main contributors to the dietary supply of these compounds associated with beneficial health effects (Sucupira et al., 2012).

Jatobá-do-cerrado (jatobá, Hymenaea stigonocarpa) belongs to the family Fabaceae and is a fruit found naturally in regions of the Brazilian Cerrado and Cerradão (Empresa Brasileira de Pesquisa Agropecuária, 2010). This fruit has potential for cultivation and marketing its by-products, for example, the flour extracted from jatobá (Âvila et al., 2010).

Popularly, the tea made with jatobá bark is used for kidney and liver diseases, intestinal infections, and even for healing and as an expectorant, and its pulp is used as a laxative (Empresa Brasileira de Pesquisa Agropecuária, 2010). A study of the methanol extract of jatobá bark in rats has demonstrated that jatobá has the capacity for medicinal treatment of gastric and duodenal ulcers and diarrhea as well, confirming popular findings (Orsi et al., 2012).

The same findings were reported in animal models of trinitrobenzenesulfonic acid-induced ulcer (Orsi et al., 2014), justifying the need to determine the antioxidant activity of this fruit. Moreover, jatobá is already commonly used in the treatment of certain diseases related to oxidative stress, and its potential in the prevention of such diseases has not yet been explored.

\section{Materials and methods}

\subsection{Raw material}

The fruits of jatobá were purchased commercially in the city of Campo Grande, MS, Brazil in February 2014, during the fruit harvest period.

In the Food Technology Unit and Public Health Laboratories of the Biological Sciences and Health Center of the Federal University of Mato Grosso do Sul (UTA-CCBS-UFMS), the fruits were washed with water and scrubbed, sanitized with bleach (150 ppm), air-dried, weighed, peeled and pulped in the dark to avoid the effect of light on the antioxidant compounds in the fruits.

The separated pulp of the fruit was homogenized and sieved (40 mesh Tamil), obtaining a mash that was packaged in plastic

Received 04 Dec., 2015

Accepted 05 Feb., 2016

${ }^{1}$ Health Multidisciplinary Residence Program, Universidade Federal da Grande Dourados - UFGD, Dourados, MS, Brazil

${ }^{2}$ Food Technology and Public Health Division, Center of Biological Sciences and Health, Universidade Federal de Mato Grosso do Sul - UFMS, Campo Grande, MS, Brazil

${ }^{3}$ School of Medicine, Universidade Federal de Mato Grosso do Sul - UFMS, Campo Grande, MS, Brazil

*Corresponding author: daniarakaki@gmail.com 
bags, stored in the dark in a biochemical oxygen demand (BOD) refrigerator at $2{ }^{\circ} \mathrm{C}$ until analysis.

Upon completion of the in vitro analysis, the extract with the highest antioxidant potential was selected for use in in vivo studies.

\subsection{Evaluation of antioxidant activity}

In vitro antioxidant activity was determined in aqueous, ethanol (with absolute ethanol) and aqueous acetone (water:acetone, 20:80) extracts. The extractions were performed with the fruit pulp. Approximately $2.5 \mathrm{~g}$ of pulp was ground in a beaker and $15 \mathrm{ml}$ of solvent were added (distilled water, ethanol or $80 \%$ acetone). The mixture of sample and solvent was homogenized using a mechanical stirrer for 20 minutes and then filtered through gauze in a glass funnel. The residue retained was recovered and extracted with $15 \mathrm{~mL}$ of fresh solvent, and the mixture was homogenized in a blender for about 20 minutes and filtered through new gauze. The second filtrate was added to the first, and finally, extraction solvent was added up to $50 \mathrm{~mL}$, providing the extracts for analysis, which were diluted 1:1 with extraction solvent.

Total in vitro antioxidant activity was determined by the DPPH method, and total phenols and tannins by the Folin Ciocalteu and Folin Denis assays, respectively.

A new aqueous acetone extract was prepared for use in animals, since this extract of jatobá pulp showed the highest antioxidant potential. Since acetone in the extract is toxic to animals, this was evaporated in a rotary evaporator and then dissolved in distilled water. Three doses of the extract were tested, 150, 250 and $500 \mu \mathrm{L}$, diluted with distilled water for administration of a total of $1 \mathrm{~mL}$.

\subsection{Experimental assay}

Male Wistar rats weaned at 21 days were used in the experiment. The animals were allowed to adapt for a week, where the animals were placed in polyethylene cages and in groups, receiving only water and food. Afterwards, the experiment was started, using a 30-day treatment period.

The distribution of animals was performed randomly as follows: eight animals in the control group (C) and 8 animals in each group treated with jatobá extract at doses of 150 (T1), 250 (T2) and $500 \mu \mathrm{L} /$ day (T3), totaling 32 animals, kept with four animals per cage. The animals were given water and commercial feed ad libitum, under a 12-hour light/ dark cycle and controlled temperature. The rats were given distilled water or extract by gavage once daily for 30 days. The control group received only $1 \mathrm{~mL}$ of distilled water, and the treated groups were given the different doses of jatobá extract in $1 \mathrm{~mL}$ of distilled water. After the treatment periods, in vivo antioxidant activity was determined by the TBARS technique, using brain tissue.

The precedures involving laboratory animals were approved by the Ethics Committee for the Use of Animals (CEUA) of the Federal University of Mato Grosso do Sul (UFMS) (Protocol No. 526/2013).

\subsection{Statistical analysis}

In vitro data showed a normal distribution, and therefore, one-way ANOVA was applied; and with significant results, a normality test was used with Tukey's post-test $(\mathrm{p}<0.05)$ for comparison of means. In vivo data showed a non-normal distribution, so the Kruskal-Wallis test was applied with Dunn's post-test.

\section{Results and discussion}

The levels of antioxidant activity, total phenols and tannins found in the pulp of jatobá are given in Table 1.

The aqueous acetone, aqueous and ethanol extracts differed significantly from each other $(\mathrm{p}<0.001)$ in relation to antioxidant activity, and the aqueous acetone extract showed the greatest inhibition of DPPH radical oxidation, followed by the aqueous and ethanol extracts.

Dias et al. (2013) found an IC50 of $5.84 \pm 0.10 \mu \mathrm{L} / \mathrm{mg}$ in the ethyl acetate fraction of the fruit pulp, lower than that found in this study, for all extractions. Compared to other fruits of the Cerrado, the IC50 values of the aqueous and aqueous acetone extracts here were lower than those found for araticum-do-mato, butiazeiro and mandacaru-de-três-quinas in extracts of mixed pulp using methanol (50\%) and aqueous acetone (70\%) (Pereira et al., 2013). The findings of this study also showed lower IC50 values when compared to those for ethanol and aqueous extracts of fruit peel and pulp of cagaita (E. klostzchiana), $(387.47 \pm 8.70$ and $879.33 \pm 11.70 \mathrm{~g} / \mathrm{g} \mathrm{DPPH}$, respectively) and araticum $(49.18 \pm 3.13$ and $198.28 \pm 8.24 \mathrm{~g} / \mathrm{g}$ DPPH, respectively), using fresh samples.

The ethanol extract was shown to be less statistically efficient in the extraction of phenols compared to the other solvents $(p<0.01)$. The aqueous acetone and aqueous extracts did not differ significantly from each other.

Rocha et al. (2013) found total phenol values of $105-385 \mathrm{mg}$ $\mathrm{TAE} / 100 \mathrm{~g}$ in aqueous acetone $(70 \%)$ extract and of $0.0-252 \mathrm{mg}$ $\mathrm{TAE} / 100 \mathrm{~g}$ in ethanol (95\%) extract for guapeva (Pouteria gardneriana), mama-cadela (Campomanesia sp.), cagaita (E. klostzchiana), cambuçá (Pliniaedulis), gabiroba (Campomanesia sp.), jaracatiá

Table 1. Antioxidant activity, total phenols and tannins in aqueous acetone, ethanol and aqueous extracts of pulp of jatobá-do-cerrado.

\begin{tabular}{|c|c|c|c|c|}
\hline & Aqueous acetone & Ethanol & Aqueous & $p$ value \\
\hline Antioxidant activity $\left(\mathrm{IC}_{50-} \mathrm{mg} / \mathrm{mg} \mathrm{DPPH}\right)^{*}$ & $<26.76^{\mathrm{a}}$ & $618.06^{c}$ & $117.07^{\mathrm{b}}$ & $<0.001$ \\
\hline Total phenols (mg GAE/100 g) & $786.18^{\mathrm{a}}$ & $444.97^{\mathrm{b}}$ & $669.64^{\mathrm{a}}$ & $<0.01$ \\
\hline Total tannins (mg TAE/100 g) & $1838.69^{a}$ & $518.43^{c}$ & $728.14^{\mathrm{b}}$ & $<0.01$ \\
\hline
\end{tabular}

Different letters in the same row indicate significant differences $(\mathrm{p}<0.01)$ according to Tukey's test. *Lower IC50 indicates greater antioxidant potential, ranked by order of letters. 
(Jaracatia spinosa), pera-do-cerrado (Eugenia klostzchiana) and pitanga-do-cerrado (Eugenia punicifolia). These values demonstrated that jatobá had a high concentration of phenols, associated with its antioxidant activity potential.

Peres et al. (2013) reported a total phenol level in the ethyl acetate extract of jatobá fruit pulp of $18 \pm 1.54 \mu \mathrm{g}$ GAE/mg of extract, finding a higher concentration of pulp phenolics in jatobá compared to other fruits of the Cerrado, such as jabuticaba (Myrciaria cauliflora) (7.92 $\pm 0.56 \mu \mathrm{g}$ GAE/mg), but showing better extraction of phenolics from the fruit peel.

Rocha et al. (2013) found higher values of GAE in ethanol extracts compared to aqueous (34.1 and $25.19 \mathrm{mg} \mathrm{GAE} / 100 \mathrm{~g}$, respectively). The values reported by these authors are below those in the present study and also those determined by Dias et al. (2013) in the oil of jatobá pulp (343 $\pm 8.0 \mathrm{mg} \mathrm{GAE} / 100 \mathrm{~g})$.

The difference in the values found may be due to the technique used, fruit characteristics (cultivation, climate, maturation stage at collection, and collection and storage characteristics) and also because of the extractions performed, since Dias et al. (2013) extracted the oil from the pulp, and in their study, aqueous and aqueous acetone extracts showed better antioxidant potential, demonstrating the polar character of the bioactive compounds in this fruit.

According to Rufino et al. (2010), phenol content can be classified as low for $<100 \mathrm{mg}$ GAE/100 g, intermediate for $100-500 \mathrm{mg} \mathrm{GAE} / 100 \mathrm{~g}$ and high for $>500 \mathrm{mg} \mathrm{GAE} / 100 \mathrm{~g}$ of fresh weight, whereas in dry matter, phenol content is classified as low for $<1000 \mathrm{mg} \mathrm{GAE} / 100 \mathrm{gm}$ intermediate for 1000-5000 GAE/100 g and high for $>5000 \mathrm{mg} \mathrm{GAE} / 100 \mathrm{~g}$, indicating that the aqueous and aqueous acetone extracts of jatobá evaluated in this study had high total phenol values .

Tannin levels were expressed in milligrams of tannic acid equivalents (TAE) in $100 \mathrm{~g}$ of sample. The aqueous, aqueous acetone and ethanol extracts were statistically different $(\mathrm{p}<0.01)$, where the aqueous acetone extract had the highest level, followed by the aqueous and ethanol extracts.

Compared to other native fruits of the Cerrado, the extracts described in this study showed a very high tannin content when compared to that obtained for the $80 \%$ methanol in water extract of jambolão, reported by Faria et al. (2011), with a mean of $3.9 \pm 0.8 \mathrm{mg}$ TAE $/ 100 \mathrm{~g}$

Arapitsas (2012) considered a mixture of water and acetone as the best solvent for the extraction of tannins, since extraction with ethanol can lead to the formation of ethyl gallate corroborating the results of this study.
In a study by Chavan \& Singhal (2013), 80\% aqueous acetone also showed greater extraction efficacy compared to pure acetone or solvent with lower acetone percentage with betel nut (Areca catechu), regarding antioxidant activity and amounts of total phenolics and tannins, corroborating the results found in this study. These results may be related to difference in polarity of solvents, which determines the dissolution of a group of antioxidant compounds, thereby influencing antioxidant activity.

In this work, at the beginning of the in vivo experiment, the animals were weighed and there was no significant difference in initial weight between groups $(p=0.899)$. The day before sacrificing, the animals were weighed again, with no significant difference in final weight between groups $(p=0.4138)$. Thus, there was no significant difference in weight gain between groups $(\mathrm{p}=0.5853)$, as shown in Table 2.

Tinkov et al. (2014) found a significant difference $(\mathrm{p}<0.05)$ in weight of animals fed diets with a high lipid content and animals with the same diet and treated with an aqueous extract of $P$. maximum. The authors attributed the antiadipogenic, antidiabetic, antiinflammatory effects and capacity to normalize the intestinal flora of the animals to bioactive components present in the extract.

In this study, with respect to the aqueous acetone extract formulated for in vivo application was tested for its antioxidant capacity, where the IC50 was $<26.44 \mathrm{mg} / \mathrm{mgDPPH}$.

After sacrificing the animals, the brain was removed of animals, and inhibition of oxidation of brain tissue was determined in treated animals relative to the control group. Inhibition of oxidation was greater with increasing concentration of extract (Graph 1).

The Control and Treatment 1 groups did not differ statistically ( $p>0.05$ ), although the latter showed showed higher inhibtion of oxidation values. Inhibtion of oxidation in brain tissue was greater according to the following order: Treatment 3 (T3) > Treatment 2 (T2) > Treatment 1 (T1) > Control (C), as shown in Table 3.

The T2 and T3 groups showed significant difference in inhibition of oxidation compared to the control group $(\mathrm{p}<0.001)$. T2 was inhibited lipid peroxidation significantly more than did T1 $(\mathrm{p}<0.05)$, and T3 was more effective compared to T2 $(\mathrm{p}<0.05)$ and $\mathrm{T} 1(\mathrm{p}<0.001)$.

The aqueous acetone extract of jatobá showed high antioxidant potential in vivo, and antioxidant activity increased with dose, and was thus dose dependent. The doses tested in the animals were equivalent to $3.75,6.25$ and $12.5 \mathrm{mg}$ /day for 150,250 and

Table 2. Initial weight, final weight and weight gain of the control and treatment groups $(\mathrm{n}=8)$, using aqueous acetone (80:20) extract of pulp of jatobá-do-cerrado.

\begin{tabular}{lcccc}
\hline \multicolumn{1}{c}{ Group/dose } & Initial $^{* *}$ & Final $^{* *}$ & Weight gain $^{\star *}$ & p value \\
\hline Control & $50.62+2.92$ & $281.50+24.04$ & 0.5853 & $230.88+22.65$ \\
Treatment $1-150 \mu \mathrm{L} /$ day & $49.50+3.38$ & $297.62+25.38$ & $218+26.50$ \\
Treatment $2-250 \mu \mathrm{L} /$ day & $49.87+4.08$ & $269.12+27.41$ & $25+28.23$ \\
Treatment $3-500 \mu \mathrm{L} /$ day & $49.50+3.11$ & $267.25+17.65$ & $217.25+18.67$ \\
\hline
\end{tabular}

\footnotetext{
${ }^{*}$ Values considered statistically significant when $\mathrm{p}<0.05 .{ }^{* *}$ Weight $(\mathrm{g})$ given as mean \pm standard deviation.
} 


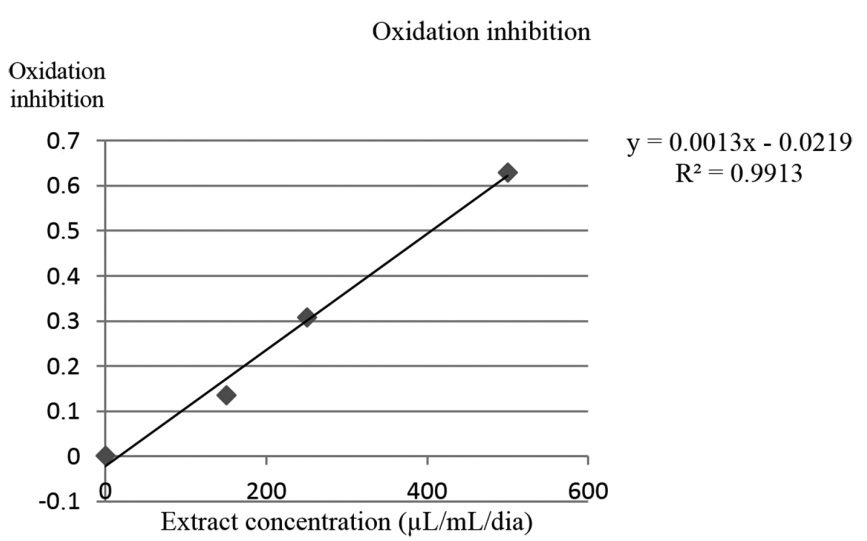

Graph 1. Inhibiton of oxidation in brain tissue of rats, according to dose of aqueous acetone extract of Jatobá-do-cerrado ( $\mu \mathrm{L} /$ day) administered.

Table 3. Percent inhibition of oxidation in rat brain tissue according to dose of te aqueous acetone extract of jatobá-do-cerrado ( $\mu \mathrm{L} /$ day) administered.

\begin{tabular}{cc}
\hline Treatment & Inhibition of oxidation - \% \\
\hline Control & $-^{\mathrm{c}}$ \\
$\mathrm{T} 1-150 \mu \mathrm{L} /$ day & $13.46^{\mathrm{c}}$ \\
$\mathrm{T} 2-250 \mu \mathrm{L} /$ day & $30.77^{\mathrm{b}}$ \\
$\mathrm{T} 3-500 \mu \mathrm{L} /$ day & $62.92^{\mathrm{a}}$ \\
\hline
\end{tabular}

Different letters indicate significant differences $(\mathrm{p}<0.05)$.

$500 \mu \mathrm{L} /$ day, respectively, amounting to $45-155 \mathrm{~mL}$ of extract/day in humans, maintaining a concentration of $2.5 \%$, as described in the in vitro assay.

In a study on coffee (Coffea arabica), Duarte et al. (2009) found $48.60 \%$ inhibition of lipid peroxidation in Wistar rats with acute treatment for 7 days and $53.40 \%$ with chronic treatment (30 days). Regarding the time of administration, the aqueous acetone extract of jatobá was more effective at inhibiting lipid peroxidation at a concentration of $500 \mu \mathrm{L} /$ day, causing $62.92 \%$ inhibition. The doses of 150 and $250 \mu \mathrm{L} /$ day caused 13.46 and $30.77 \%$ inhibition, respectively,

In the aqueous extract of the bark of $S$. henningsii Gilg., an African shrub, Oyedemi et al. (2010) found dose-dependent inhibition of lipid peroxidation with eight days of treatment. This extract was able to inhibit lipid peroxidation by up to $47-58 \%$, which was somewhat lower than with the highest dose of the aqueous acetone extract of jatobá.

However, the concentrations used in preparing the coffee and $S$. henningsii extracts were respectively 10 and $6 \%$, while the concentration of the extracts used here was $2.5 \%$. Thus, when compared with these extracts, we see that even a low concentration of the aqueous acetone extract of jatoba had a high antioxidant potential in vivo (Duarte et al., 2009); (Oyedemi et al., 2010).

Although the aqueous acetone extract was shown to have higher antioxidant potential in vitro, an in vitro study does not take into account particular in vivo processes such as digestion, absorption and metabolism, the combination of factors to which living organisms may be exposed, and other metabolic factors that can increase or decrease oxidative stress (the presence of diseases, stress, and combination of endogenous and dietary exogenous antioxidants) (Prior \& Wu, 2013).

For the antioxidant potential of jatobá extracts cannot be assigned to a single bioactive component, since both in vitro and in vivo, antioxidant potential increases in the presence of more than one bioactive compound, because they can act synergistically or antagonistically with each other (Hidalgo et al., 2010). But it is possible to correlate the antioxidant activity described with extraction of total phenols and tannins, highlighting the importance of these bioactive compounds inthe antioxidant capacity of these extracts studied. These results corroborate those obtained by Lopes et al. (2012), who found a positive correlation between the amount of phenolics and antioxidant activity.

\section{Conclusions}

All extracts exhibited antioxidant activity, and the aqueous acetone extract had the lowest IC50, followed by the ethanol and aqueous extracts. The extraction of phenols and tannins followed the same pattern, where the aqueous acetone extract showed higher levels of phenols and tannins than did the aqueous and ethanol extracts.

The aqueous acetone extract inhibited lipid peroxidation in rat brain tissue at all concentrations used and in a concentration-dependent manner.

The aqueous acetone extract showed high antioxidant potential both in vitro and in vivo, probably due to the diversity and high concentration of bioactive compounds present, which can act synergistically.

\section{References}

Abrahão, S. A., Pereira, R. G. F. A., Sousa, R. V., \& Lima, A. R. (2012). Atividade antioxidante in vitro e in vivo de café bebida mole. Pesquisa Agropecuária Brasileira, 47(1), 127-133. http://dx.doi.org/10.1590/ S0100-204X2012000100017.

Alves, C. Q., David, J. M., David, J. P., Bahia, M. V., \& Aguiar, R. M. (2010). Métodos para determinação de atividade antioxidante in vitro em substratos orgânicos. Química Nova, 33(10), 2202-2210. http://dx.doi.org/10.1590/S0100-40422010001000033.

Arapitsas, P. (2012). Hydrolyzable tannin analysis in food. Food Chemistry, 135(3), 1708-1717. http://dx.doi.org/10.1016/j.foodchem.2012.05.096. PMid:22953913.

Ávila, R., Oliveira, L. F., \& Ascheri, D. P. R. (2010). Caracterização dos frutos nativos dos cerrados: Araticum, Baru e Jatobá. Agrotecnologia, 1(1), 53-69. http://dx.doi.org/10.12971/2179-5959.v01n01a04.

Chavan, Y. V., \& Singhal, R. S. (2013). Separation of polyphenols and arecoline from arecanut (Areca Catechu L.) by solvent extraction, its antioxidant activity, and identification of polyphenols. Journal of the Science of Food and Agriculture, 93(10), 2580-2589. http:// dx.doi.org/10.1002/jsfa.6081. PMid:23494978.

Dias, L. S., Luzia, D. M. M., \& Jorge, N. (2013). Physicochemical and bioactive properties of Hymenaea courbaril L. pulp and seed lipid fraction. Industrial Crops and Products, 49, 610-618. http://dx.doi. org/10.1016/j.indcrop.2013.06.005.

Duarte, S. M. S., Abreu, C. M. P., Menezes, H. C., Paula, F. B. A., Pereira, R. G. F. A., \& Gouvêa, C. M. C. P. (2009). Efeito da bebida de café descascado sobre a atividade antioxidante, os parâmetros hematológicos 
e bioquímicos em ratos. Ciência e Tecnologia de Alimentos, 29(4), 703-708. http://dx.doi.org/10.1590/S0101-20612009000400001.

Empresa Brasileira de Pesquisa Agropecuária - EMBRAPA. (2010). Jatobá-do-cerrado: composição nutricional e beneficiamento dos frutos (Documentos). Planaltina: Embrapa Cerrados.

Faria, A. F., Marques, M. C., \& Mercadante, A. Z. (2011). Identification of bioactive compounds from jambolão (Syzygium cumini) and antioxidant capacity evaluation in different $\mathrm{pH}$ conditions. Food Chemistry, 126(4), 1571-1578. http://dx.doi.org/10.1016/j. foodchem.2010.12.007. PMid:25213929.

Hidalgo, M., Sánchez-Moreno, C., \& Pascual-Teresa, S. (2010). Flavonoid-flavonoid interaction and its effect on their antioxidant activity. Food Chemistry, 121(3), 691-696. http://dx.doi.org/10.1016/j. foodchem.2009.12.097.

Lopes, M. M. A., Miranda, M. R. A., Moura, C. F. H., \& Enéas, J. Fo. (2012). Bioactive compounds and total antioxidant capacity of cashew apples (Anacardium occidentale L.) during the ripening of early dwarf cashew clones. Ciência e Agrotecnologia, 36(3), 325-332. http://dx.doi.org/10.1590/S1413-70542012000300008.

Orsi, P. R., Bonamim, F., Severi, J. A., Santos, R. S., Vilegas, W., HirumaLima, C. A., \& Stasi, L. C. (2012). Hymenaea stigonocarpa Mart. ex Hayne: a Brazilian medicinal plant with gastric and duodenal antiulcer and antidiarrheal effects in experimental rodent models. Journal of Ethnopharmacology, 143(1), 81-90. http://dx.doi.org/10.1016/j. jep.2012.06.001. PMid:22750452.

Orsi, P. R., Seito, L. N., \& Di Stasi, L. C. (2014). Hymenaea stigonocarpa Mart. ex Hayne: a tropical medicinal plant with intestinal antiinflammatory activity in TNBS model of intestinal inflammation in rats. Journal of Ethnopharmacology, 151(1), 380-385. http://dx.doi. org/10.1016/j.jep.2013.10.056. PMid:24211392.

Oyedemi, S. O., Bradley, G., \& Afolayan, A. J. (2010). In vitro and in vivo antioxidant activities of aqueous extract of Strychnos henningsii Gilg. African Journal of Pharmacy and Pharmacology. 4 (2): 70-78.
Pereira, M. C., Steffens, R. S., Jablonski, A., Hertz, P. F., Rios, A. O., Vizzotto, M., \& Flôres, S. H. (2013). Characterization, bioactive compounds and antioxidant potential of three Brazilian fruits. Journal of Food Composition and Analysis, 29(1), 19-24. http:// dx.doi.org/10.1016/j.jfca.2012.07.013.

Peres, M. T. L. P., Lopes, J. R. R., Silva, C. B., Cândido, A. C. S., Simionatto, E., Cabral, M. R. P., Oliveira, R. M., Facco, J. T., Cardoso, C. A. L., \& Simas, P. H. (2013). Phytotoxic and antioxidant activity of seven native fruits of Brazil. Acta Botanica Brasílica, 27(4), 836-846. http:// dx.doi.org/10.1590/S0102-33062013000400024.

Prior, R. L., \& Wu, X. (2013). Diet antioxidant capacity: relationships to oxidative stress and health. American Journal of Biomedical Sciences, 5(2), 126-139. http://dx.doi.org/10.5099/aj130200126.

Rocha, M. S., Figueiredo, R. W., Araújo, A. M. A., \& Moreira-Araújo, R. S. R. (2013). Caracterização físico-química e atividade antioxidante (in vitro) de frutos do cerrado piauiense. Revista Brasileira de Fruticultura, 35(4), 933-941. http://dx.doi.org/10.1590/S010029452013000400003.

Rufino, M. S. M., Alves, R. E., Brito, E. S., Pérez-Jiménez, J., SauraCalixto, F., \& Mancini-Filho, J. (2010). Bioactive compounds and antioxidant capacities of 18 non-traditional tropical fruits from Brazil. Food Chemistry, 121(4), 996-1002. http://dx.doi.org/10.1016/j. foodchem.2010.01.037.

Sucupira, N. R., Silva, A. B., Pereira, G., \& Costa, J. N. (2012). Métodos para determinação da atividade antioxidante de frutos. Revista Unopar Científica Ciências Biológicas e da Saúde, 14(4), 263-269.

Tinkov, A. A., Nemereshina, O. N., Popova, E. V., Polyakova, V. S., Gritsenko, V. A., \& Nikonorov, A. A. (2014). Plantago maxima leaves extract inhibits adipogenic action of a high-fat diet in female Wistar rats. European Journal of Nutrition, 53(3), 831-842. http://dx.doi. org/10.1007/s00394-013-0587-6. PMid:24077693. 